\title{
PENGARUH VARIASI PELARUT EKSTRAKSI DAN DAYA SIMPAN TERHADAP KADAR ANTOSIANIN DALAM TES KIT UJI FORMALIN BERBAHAN DASAR UBI JALAR UNGU (Ipomoea batatas L. Poir)
}

\author{
EFFECT OF VARIATION EXTRACTION SOLVENTS AND STORAGE CAPACITY ON \\ ANTHOCYANIN CONCENTRATION IN THE TEST KIT MADE FROM PURPLE SWEET \\ POTATO (Ipomoea batatas L. Poir)
}

\author{
Danis Alfitasari ${ }^{1}$, Zuri Rismiati $^{1^{*}}$, Sulistiastutik $^{1}$ \\ ${ }^{1}$ Program Studi D3 Anafarma, Jurusan Gizi, Politeknik Kesehatan Kemenkes Malang \\ Jalan Besar Ijen 77 C, Kota Malang, Kode Pos 6511, Indonesia \\ "zuri rismiarti@poltekkes-malang.ac.id
}

\begin{abstract}
Abstrak
Formalin merupakan salah satu bahan pencemar kimia yang memberikan efek negatif bagi tubuh. Evaluasi dan monitoring peredaran makanan diperlukan untuk memastikan makanan yang dikonsumsi aman. Tujuan dari penelitian ini adalah pembuatan tes kit uji formalin berbahan dasar ubi jalar ungu untuk memaksimalkan potensi alam dalam rangka membantu mengawasi peredaran makanan berbahaya. Tahapan penelitian yang dilakukan adalah ekstraksi antosianin ubi jalar ungu, optimasi larutan ekstrak antosianin dengan formalin, uji daya simpan, dan uji validasi. Hasil menunjukkan ekstrak dengan pelarut etanol $96 \%$ memiliki warna coklat dengan $\mathrm{pH} 5$ dan berwarna merah dengan $\mathrm{pH} 0$ untuk ekstrak menggunakan pelarut etanol $96 \%$ dengan $\mathrm{HCl} 1,5$ M. Hasil optimasi larutan ekstrak dengan formalin menunjukkan perubahan warna signifikan dengan perbandingan 1:10 pada ekstrak menggunakan pelarut etanol 96\% dan 1:20 untuk ekstrak dengan pelarut etanol 96\% dengan $\mathrm{HCl}$ 1,5 M. Pengujian daya simpan pada masing-masing pelarut menunjukkan bahwa ekstrak dengan pelarut asam lebih stabil daripada ekstrak yang menggunakan pelarut netral. Hasil uji validasi dapat diketahui bahwa ekstrak antosianin ubi jalar ungu mampu mengidentifikasi adanya kandungan formalin dalam makanan. Hasil perubahan warna signifikan pada pangan yang diuji ditunjukkan pada ekstrak antosianin dengan menggunakan pelarut bersifat asam yaitu etanol 96\% dan $\mathrm{HCl} 1,5 \mathrm{M}$.
\end{abstract}

Kata kunci: formalin, tes kit, ubi jalar ungu

\begin{abstract}
Formalin is a chemical pollutant that has a negative effect on the body. Evaluation and monitoring of food circulation is needed to ensure the food consumed is safe. The purpose of this research is to make a formalin test kit made from purple sweet potato to maximize the natural potential in order to help monitor the circulation of dangerous foods. The steps of the research that have been carried out are extraction of purple sweet potato anthocyanins, optimization of the anthocyanin extract solution with formaldehyde, the shelf life test, and validation test. The result showed that the extract with $96 \%$ ethanol sovent had a brown color with a pH of 5 and red color with a pH of 0 the extract using ethanol $96 \%$ with 1,5 $\mathrm{M} \mathrm{HCl}$ solvent. The optimization result of extract solution with formalin showed a significant color change with a ratio of 1:10 in the extract using ethanol 96\% solvent and 1:20 for extract with ethanol $96 \%$ and 1,5 M of HCl solvent. The shelf life test of each solvent showed tha the extract with an acid solvent was more stable than the extract using a neutral solvent. The result of validation test show tha the anthocyanin extract of purple sweet potato is able to identify the presence of formaldehyde in food. The result of significant color changes in the food tested were shown in anthocianin extracts using acidic solvents or ethanol $96 \%$ with 1,5 $\mathrm{M}$ of $\mathrm{HCl}$.
\end{abstract}

Keywords : formalin, test kit, purple sweet potato

\section{Pendahuluan}

Penggunaan bahan pengawet formalin sudah dilarang oleh pemerintah sesuai dengan Peraturan Menteri Kesehatan Republik Indonesia No. 1168/MENKES/PER/X/1999 perubahan dari Peraturan Menteri Kesehatan No. 722/MENKES/IX/1998 tentang bahan tambahan makanan.

Sesuai dengan International Programme on Chemical Safety (IPCS), ambang batas formalin yang boleh masuk ke dalam tubuh manusia adalah $1 \mathrm{mg} / \mathrm{L}$. Apabila melebihi ambang batas tersebut, formalin dapat menimbulkan dampak buruk bagi kesehatan dan keselamatan manusia (Cahyadi, 2012).

Metode uji cepat (rapid test kit) uji formalin merupakan implementasi dari teknologi penapisan berisi seperangkat alat untuk pengujian cepat adanya kandungan formalin dalam makanan. Metode ini dibutuhkan untuk membantu dalam pengawasan peredaran makanan yang dicurigai mengandung formalin didalamnya. 
Deteksi formalin dalam makanan secara kualitatif dapat dilakukan menggunakan bahan alam yaitu ubi jalar ungu dengan memanfaatkan kandungan antosianin didalamnya. Ekstrak antosianin dari ubi jalar ungu telah teruji mampu mendeteksi adanya kandungan formalin dalam makanan dengan munculnya perubahan warna yang lebih terlihat ketika diuji pada sampel dari pada menggunakan sumber antosianin lain seperti buah naga dan anggur. Perubahan warna yang terlihat dipengaruhi oleh kadar antosianin dalam tanaman tersebut. Tanaman ubi jalar ungu memiliki kadar antosianin sebesar $519 \mathrm{mg}$, buah stroberi memiliki kadar antosianin $69 \mathrm{mg}$, pada buah naga sebesar 104,58 mg, dan buah anggur yang memiliki kadar antosianin sebesar $6 \mathrm{mg}$. Hal tersebut yang mendasari pembuatan reagen tes kit untuk menguji adanya formalin secara semi kualitatif berbahan dasar ubi jalar ungu.

Tahapan pembuatan tes kit formalin dari ubi jalar ungu diawlai dengan proses ekstraksi dengan metode maserasi agar senyawa antosianin yang diperoleh tidak rusak. Selanjutnya dilakukan optimasi perbandingan antara larutan ekstrak antosianin dengan formalin untuk mengetahui perbandingan larutan yang mengakibatkan perubahan warna signifikan. Perbandingan larutan tersebut kemudian digunakan sebagai acuan dalam uji daya simpan tes kit. Terakhir tes kit yang telah dibuat kemudian di validasi dengan membandingkan dengan regen schiff,s pada sampel yang mengandung formalin.

Penelitian ini bertujuan mengembangkan sebuah prototipe tes kit berbahan baku ubi ungu yang mampu digunakan sebagai uji formalin dalam makanan yang mudah dilakukan oleh masyarakat umum, cepat, murah, akurat, ramah lingkungan, dan aman untuk mengawasi peredaran makanan berformalin.

\section{Teori}

Analisis kandungan formalin dalam makanan dapat dilakukan dengan menggunakan metode kualitatif dan kuantitatif. Metode kualitatif bertujuan untuk mengetahui ada atau tidaknya kandungan formalin dalam makanan. Analisis kualitatif formalin dapat dilakukan menggunakan pereaksi-pereaksi kimia yang dapat menimbulkan kompleks warna khas apabila sampel positif formalin.Penggunaan pereaksi kimia dapat membahayakan pengguna apabila tidak memahami sifat dari pereaksi yang digunakan. Penggunaan pereaksi dari alam untuk mendeteksi formalin telah dibuktikan oleh Nuhman (2017) menggunakan zat antosianin yang terkandung dalam tanaman buah naga, ubi ungu, stroberi, dan anggur. Penelitian tersebut menghasilkan ekstrak antosianin yang mampu mendeteksi formalin dalam makanan dengan adanya perubahan warna pada sampel positif formalin. Hasil penelitian tersebut menyebutkan bahwa kandungan antosianin pada ubi ungu mampu memberikan gradasi warna yang kuat dari pada dari buah lain yang digunakan untuk menguji formalin dalam makanan. Antosianin merupakan pigmen alami yang dapat terkandung dalam sel-sel epidermis buah, akar, dan daun dari beberapa jenis sayuran (Hidayat dan Saati, 2006).

Antosianin dapat terekstrak dengan maksimal menggunakan larutan metanol yang diasamkan dengan $\mathrm{HCl}$. Hal tersebut berdasar pada kestabilan antosianin yang stabil pada $\mathrm{pH}$ yang cenderung asam. Namun, metanol berbahaya dan dapat mengakibatkan toksik dalam sistem pangan. Oleh sebab itu, pelarut yang sering digunakan untuk mengekstrak antosianin adalah akuades atau etanol yang diasamkan menggunakan larutan $\mathrm{HCl}$.

Tes kit adalah alat maupun bahan yang telah diolah sedemikian rupa untuk menguji secara cepat kandungan berbahaya dalam suatu sampel, baik sampel makanan maupun minuman. Tes kit berbahan dasar bahan alami memiliki kelebihan yaitu lebih aman digunakan atau apabila terkena tubuh dibanding dengan tes kit berbahan dasar bahan kimia, ramah lingkungan, sumber daya yang digunakan tersedia dalam jumlah besar dan mudah ditemukan, dapat meningkatkan nilai pemanfaatan sumber daya alam, dan mampu meningkatkan harga jual atau nilai ekonomi dari sumber daya alam tersebut.

\section{Metode penelitian}

\section{Jenis penelitian}

Jenis penelitian yang dilakukan adalah eksperimental. Rancangan penelitia yang digunakan adalah penelitian acak lengkap (RAL) dengan variabel peubah yang digunakan adalah pengujian daya simpan terhadap variabel terikat kadar antosianin dalam tes kit uji formalin berbahan dasar ubi jalar ungu.

\section{Alat dan bahan}

Alat Peralatan yang digunakan untuk melakukan penelitian ini adalah pisau, talenan, blender, toples, kertas saring, labu takar $100 \mathrm{ml}$, pipet tetes, bola hisap, gelas kimia 1L, batang pengaduk, spatula, kaca arloji, neraca analitik, gunting, corong gelas, tabung reaksi dan wadah gelap untuk sampel.

Bahan Bahan-bahan yang digunakan dalam penelitian ini adalah ubi jalar ungu yang dibeli di daerah Lawang, Kabupaten Malang, Jawa Timur. Ubi jalar ungu yang digunakan memiliki ciri-ciri fisik kulit yang segar dan mulus, aroma khas ubi, dan memiliki massa dan ukuran yang medium. Bahan yang digunakan selanjutnya adalah aquades, etanol $96 \%$, formalin $37 \%, \mathrm{HCl} \mathrm{1,5} \mathrm{M,} \mathrm{tahu} \mathrm{dan} \mathrm{ikan} \mathrm{tongkol.} \mathrm{Bahan-bahan} \mathrm{kimia}$ yang digunakan bersifat teknis. 


\section{Analisis data}

Data yang diperoleh berupa data kualitatif dan kuantitif dari masing masing perlakuan pada optimasi perbandingan volume larutan ekstrak antosianin dan larutan formalin, pengaruh daya simpan, dan uji validasi. Hasil uji kualitatif ditunjukkan dengan adanya perubahan warna pada sampel yang positif mengandung formalin dengan indikasi munculnya warna ungu pada sampel yang telah ditetesi reagen ekstrak antosianin.

Jenis analisis data yang digunakan adalah analisis ragam (Analisis of varian) untuk menguji perlakuan (jenis pelarut yang digunakan dan lama waktu ekstraksi) terhadap nilai absorbansi apakah ada pengaruhnya atau tidak. Sedangkan uji setelah analisis ragam diperlukan untuk mengetahui apa ada perbedaan antara nilai absorbansi larutan ekstrak antosianin dari hari pertama sampai hari kelima penyimpanan dengan menggunakan uji LSD atau uji Duncan.

Pada penelitian ini nilai absorbansi digunakan untuk mengetahui kadar antosianin dalam suatu larutan. Adapun persamaan Lambert-Beer yang digunakan adalah sebagai berikut.

$$
\begin{aligned}
& \quad \text { Absorbansi }=-\log \frac{\mathrm{I}}{\mathrm{Io}} \ldots \ldots . . .(1) \\
& \text { Keterangan }= \\
& \mathrm{I}=\text { nilai intensitas larutan uji }(255 \mathrm{~cm}) \\
& \mathrm{Io}=\text { nilai intensitas larutan standar (blanko) }(\mathrm{cm})
\end{aligned}
$$

\section{Hasil}

\section{Ekstrak Antosianin Ubi Jalar Ungu (Ipomoea batatas L. Poir)}

Penggunaan dua jenis pelarut pada proses ekstraksi bertujuan untuk mengetahui keefektifan ekstraksi antosianin pada larutan $\mathrm{pH}$ netral menggunakan pelarut etanol $96 \%$ dan larutan $\mathrm{pH}$ asam menggunakan larutan etanol 96\% dengan $\mathrm{HCl}$ 1,5 M (4:1). Ekstraksi antosianin dari ubi jalar ungu dengan metode maserasi dilakukan dalam wadah yang ditutup dan dilapisi alumunium foil kemudian ditempatkan di tempat yang gelap dan bersuhu $\pm 25^{\circ} \mathrm{C}$ (suhu ruang), hal tersebut dilakukan karena suhu, cahaya, serta oksigen mampu menyebabkan kerusakan dan perubahan struktur antosianin sehingga ekstrak menjadi tidak berwarna, kemudian ekstrak disaring untuk memisahkan filtrat dengan pengotor lainnya. Ekstrak yang didapat dari masing-masing maserasi memiliki perbedaan warna dan nilai $\mathrm{pH}$. Ekstrak antosianin dengan pelarut etanol 96\% memiliki warna coklat dengan nilai pH 5 dan memiliki aroma khas etanol dan ubi jalar ungu, sedangkan untuk ekstrak antosianin yang diperoleh menggunakan pelarut etanol 96\% dengan $\mathrm{HCl}$ 1,5M (4:1) memiliki warna merah dengan nilai $\mathrm{pH}$ larutan 0 dan memiliki aroma menyengat karena pelarut $\mathrm{HCl}$ yang digunakan.

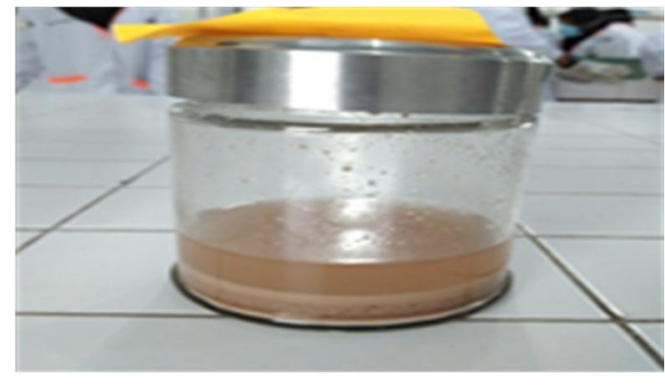

Gambar 1. Ekstrak dengan pelarut asam

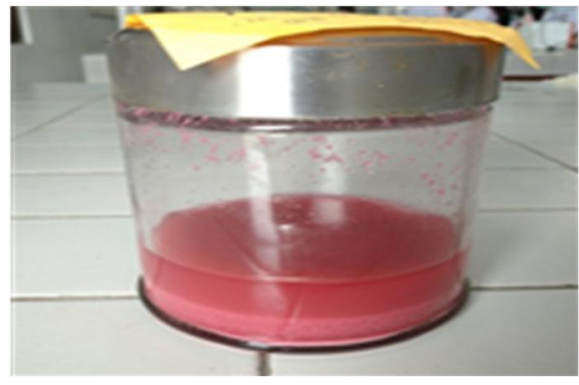

Gambar 2. Ekstrak dengan pelarut netral

Optimasi Perbandingan Volume Larutan Ekstrak Antosianin Ubi Jalar Ungu dengan Larutan Formalin Optimasi perbandingan volume larutan ekstrak ubi jalar ungu dengan larutan formalin bertujuan untuk mengetahui rasio optimum antara larutan ekstraks ubi jalar ungu dengan larutan formalin. Dengan mengatahui rasio optimum tersebut dapat diketahui komposisi yang tepat dalam proses pembuatan tes kit formalin berbahan dasar ubi jalar ungu,. Rasio volume larutan ekstrak ubi jalar ungu dengan larutan formalin menunjukkan perubahan warna yang berbeda pula seperti yang ditunjukkan dalam lampiran gambar berikut. 

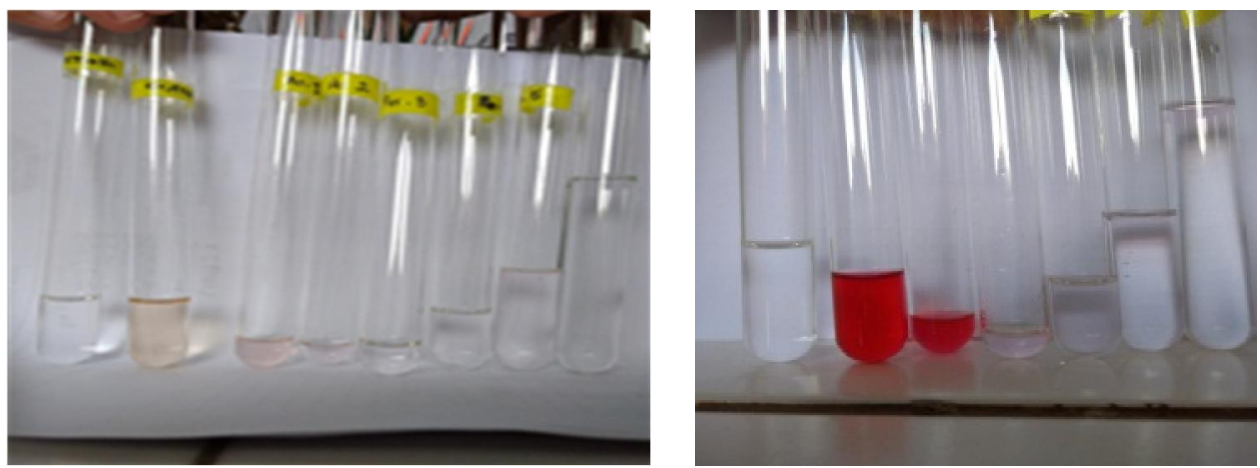

Gambar 3. Rasio larutan ekstrak:formalin, (kiri: pelarut etanol 96\%, kanan: pelarut etanol 96\% dengan $\mathrm{HCl}$ 1,5M)

Untuk mengetahui nilai intensitas dan absorbansi larutan maka larutan ekstrak antosianin dengan formalin digunakan metode pencitraan digital menggunakan aplikasi Photoshop CS4. Hasil analisis optimasi perbandingan volume larutan ekstrak antosianin dengan formalin kemudian diolah menggunakan program

microsoft excel untuk mengetahui nilai absorbansi larutan tersebut. Grafik rasio larutan ekstrak antosianin dengan larutan formalin dapat dilihat pada gambar 4 dan 5. Hasil grafik menunjukkan bahwa rasio 1:10 pada maserasi menggunakan pelarut etanol 96\% memiliki nilai absorbansi paling tinggi dibandingkan dengan rasio yang lainnya dengan nilai 0,29595, sedangkan rasio larutan ekstrak antosianin dengan formalin 1:20 memiliki nilai absorbansi tertinggi dibandingkan rasio lainnya pada maserasi menggunakan pelarut etanol $96 \%$ dengan $\mathrm{HCl} 1,5 \mathrm{M}$ dengan nilai 0,393703. Berdasarkan data tersebut rasio yang digunakan untuk test kit formalin dengan ekstrak antosianin ubi jalar ungu adalah rasio 1:10 pada maserasi menggunakan pelarut etanol 96\% dan rasio 1:20 untuk maserasi menggunakan pelarut etanol 96\% dengan $\mathrm{HCl}$ 1,5 M.

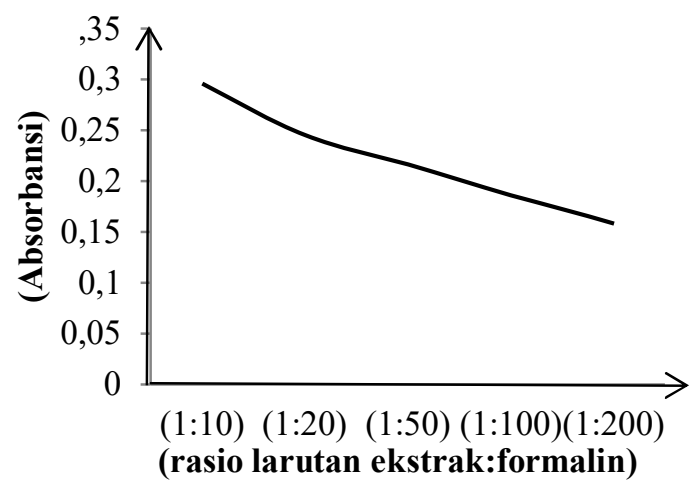

Gambar 4. Grafik rasio larutan ekstrak antosianin dengan formalin pada maserasi menggunakan pelarut etanol $96 \%$ dengan $\mathrm{HCl} 1,5 \mathrm{M}$

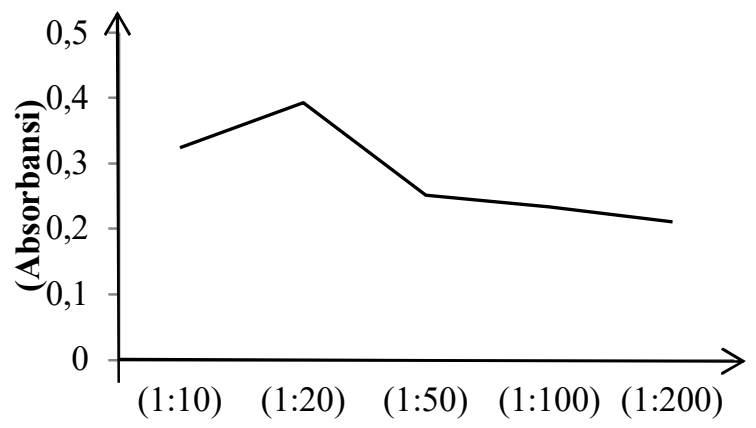

(Rasio larutan ekstrak : formalin)

Gambar 5. Grafik rasio larutan ekstrak antosianin dengan formalin pada maserasi menggunakan pelarut etanol $96 \%$ (netral) 


\section{Pengujian daya simpan}

Dasaran nilai perbandingan larutan ekstrak dan formalin tersebut digunakan sebagai acuan untuk menguji daya simpan dari ekstrak antosianin masing-masing pelarut. Pengujian daya simpan dilakukan dalam tempo waktu 5 hari dimulai ekstrak tersebut diperoleh atau hari ke 0 dan diukur intensitas warnanya setiap 24 jam sekali. Pengujian daya simpan memanfaatkan metode pencitraan digital untuk mengetahui nilai absorbansi larutan dimana nilai absorbansi tersebut sebanding dengan konsentrasi ekstrak pada setiap waktu pengujian.

Hasil dari absorbansi pengujian daya simpan dari masing-masing pelarut kemudian diuji menggunakan aplikasi uji statistik IBM SPSS statistic 21 dengan rancangan yang digunakan adalah rancangan acak lengkap menggunakan variabel dependen absorbansi larutan dan variasi independen masa simpan dari larutan tersebut dan analisis yang digunakan adalah One Way Anova, sehingga diperoleh grafik regresi sebagai berikut.

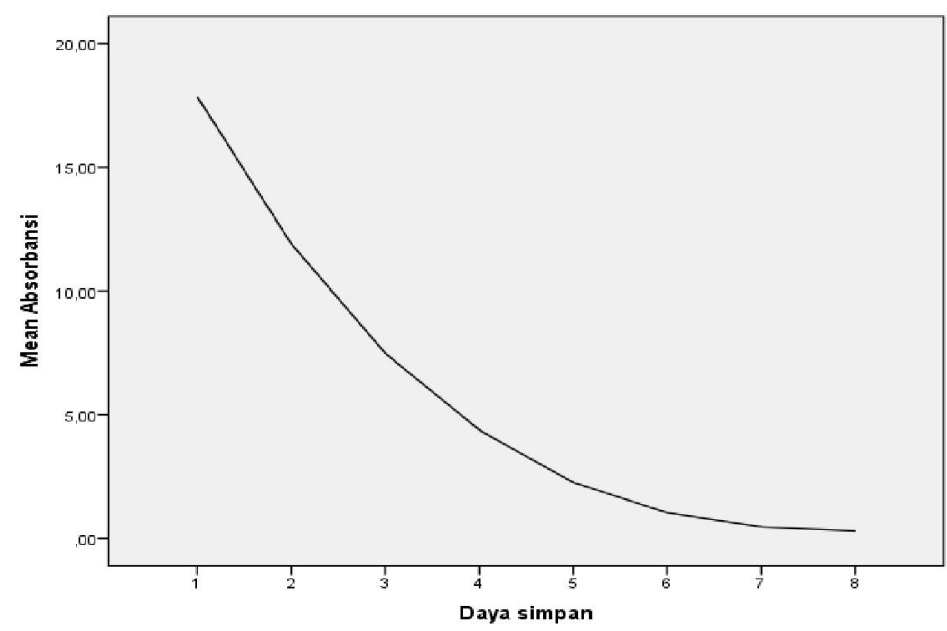

Gambar 6. Grafik regresi pengujian daya simpan larutan ekstrak antosianin dengan pelarut etanol 96\%

Grafik regresi tersebut menunjukkan bahwa terjadi penurunan nilai absorbansi larutan ekstrak antosianin. Penurunan nilai absorbansi mula-mula cepat kemudian melambat dan kurang stabil .

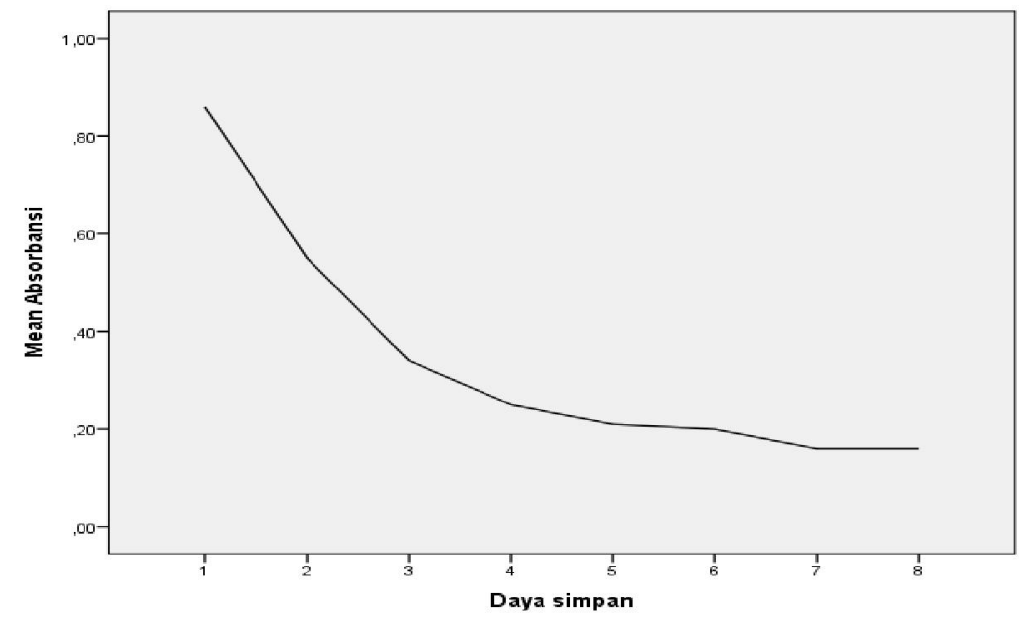

Gambar 7. Grafik regresi pengujian daya simpan larutan ekstrak antosianin dengan pelarut etanol $96 \%$ + HCl $1,5 \mathrm{M}$

Hasil grafik regresi tersebut menyatakan bahwa terjadi penurunan ekstrak antosianin setiap harinya. Penurunan ekstrak mula-mula terjadi cepat kemudian melambat dan cenderung stabil. 


\section{Uji Validasi pada Sampel Pangan}

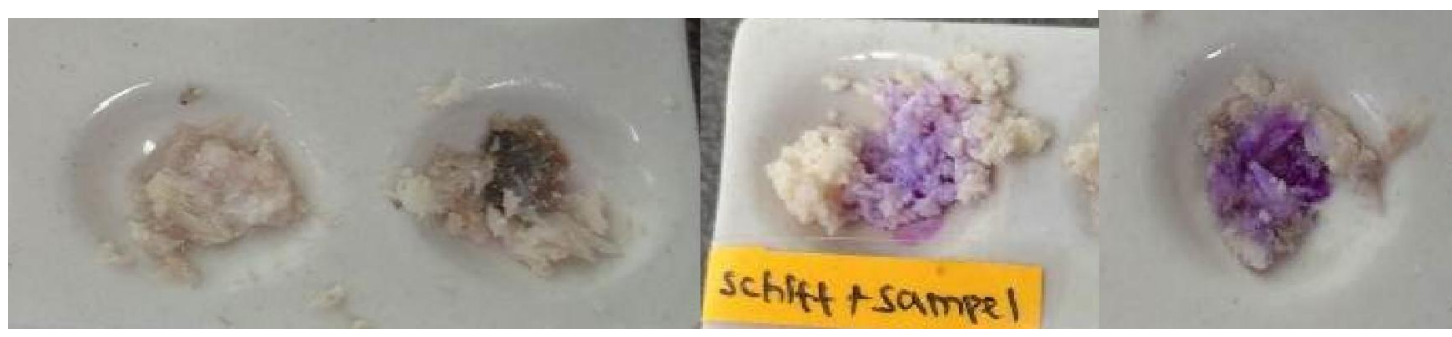

Sampel

Sampel ditambah Schiff's

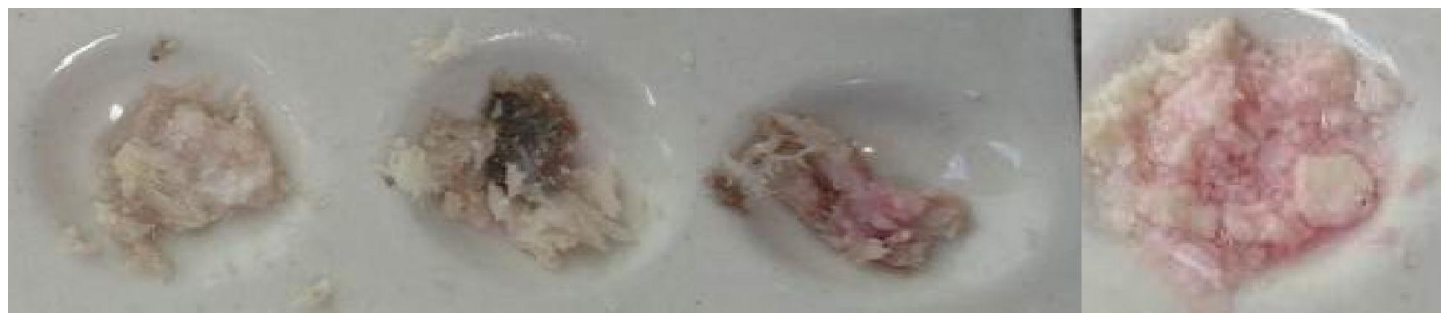

Sampel ditambah ekstrak dengan pelarut etanol 96\%

Sampel ditambah ekstrak dengan pelarut etanol 96 dengan $\mathrm{HCl}$ 1,5 $\mathrm{M}$

\section{Gambar 8. Uji validasi}

Uji validasi menunjukkan bahwa pereaksi schiff's menampilkan uji positif pada sampel pangan ikan tongkol dan tahu yang sudah direndam formalin ditandai dengan adanya perubahan warna yaitu menjadi ungu. Uji adanya kandungan formalin pada pangan menggunakan ekstrak antosianin dengan pelarut etanol $96 \%$ dan pelarut $96 \%+\mathrm{HCl} 1,5 \mathrm{M}$ memiliki perbedaan. Hasil uji warna menunjukkan bahwa pengujian dengan menggunakan ekstrak antosianin yang menggunakan pelarut asam dapat lebih terlihat perubahan warnanya yakni menjadi keunguan dari pada pengujian pangan berformalin menggunakan ekstrak antosianin dengan pelarut etanol $96 \%$.

\section{Kesimpulan}

Ekstrak antosianin yang diperoleh dari proses maserasi berwarna coklat dengan $\mathrm{pH} 5$ untuk ekstrak menggunakan pelarut etanol 96\% dan berwarna merah dengan $\mathrm{pH} 0$ untuk ekstrak menggunakan pelarut etanol 96\% dengan $\mathrm{HCl}$ 1,5 M. Hasil uji perbandingan larutan ekstrak antosianin dengan larutan formalin pada ekstrak menggunakan pelarut etanol 96\% adalah 1:10 dengan nilai absorbansi larutan 0,29595 dan untuk ekstrak menggunakan pelarut etanol 96\% dengan $\mathrm{HCl}$ 1,5 M adalah 1:20 dengan nilai absorbansi larutan 0,393703.

\section{Ucapan Terima Kasih}

Sehubungan dengan selesainya penelitian ini, penulis ingin mengucapkan terima kasih kepada:

1. Direktur Politeknik Kesehatan Kemenkes Malang

2. Ketua Jurusan Gizi - Politeknik Kesehatan Kemenkes Malang

3. Dra. Sulistiastutik, M.Kes selaku Ketua Program Studi D3 Analisis Farmasi dan Makanan Politeknik Kesehatan Kemenkes Malang merangkap Ketua Penguji

4. Zuri Rismiati, S.Si., M.Si selaku Anggota Penguji

5. Serta semua pihak yang telah membantu dalam penulisan Karya Tulis Ilmiah ini.

Penulis menyadari bahwa dalam melakukan penelitian ini masih terdapat banyak kekurangan dan jauh dari kesempurnaan, untuk itu penulis mengharapkan kritik dan saran yang bersifat membangun demi kesempurnaan penelitian ini. 


\section{Daftar Pustaka}

Afandy, Moh. Azhar, Nuryanti, dan Anang. 2017. Ekstraksi Ubi Jalar Ungu (Ipoema batatas L.) Menggunakan Variasi Pelarut Serta Pemanfaatannya sebagai Indikator Asam-Basa. Palu. Pendidikan Kimia/FKIPUniversitas Tadulako, Palu.

Alsuhendra dan Ridawati. 2013 . Bahan Toksik dalam Makanan. Jakarta. Rosda.

Andriyani. 2015. Pemanfaatan Antosianin pada Ubi Jalar Ungu (Ipoema batatas L.) Sebagai Indikator AsamBasa. Semarang. Jurusan Kimia FMIPA Universits Semarang.

Badan Pengawas Obat dan Makanan RI. 2003. Keamanan Pangan. Deputi Bidang Pengawasan Keamanan Pangan dan Bahan Berbahaya. Badan Pengawas Obat dan Makanan RI. Jakarta.

Badan Pengawas Obat dan Makanan. 2015. Pedoman Gerakan Nasional Peduli Obat dan Pangan Aman untuk Dewasa. Jakarta. Badan POM

Departemen Kesehatan. 2006. Monografi Ekstrak Tumbuhan Obat Indonesia. Volume 2, 124. Depkes RI. Jakarta.

Dewi, R. 2019. Identifikasi Formalin pada Makanan Menggunakan Ekstrak Kulit Buah Naga. Volume 2. Edisi 1 Lembaga Penelitian dan Pengabdian Kepada Masyarakat Universitas Hasanuddin JURNAL NASIONAL ILMU KESEHATAN (JNIK). Samarinda.

Fardiaz, S. 2007. Bahan Tambahan Makanan. nstitut Pertanian Bogor. Bandung. http://perpustakaan.pom.go.id/KoleksiLainnya/Buletin\%20Info\% 20POM/0110.pdf. Diakses pada tanggal 18 Agustus 2019

Fessenden R.J. and Fessenden J.S. 1986. Kimia Organik Edisi Ketiga. Diterjemahkan oleh : Pudjaatmaka, A. H. Penerbit Erlangga, Jakarta.

GLASSTON, S. 1960. Textbook of Physical Chemistry. 2nd ed. Macmillan and Co. Ltd. London.

Hastuti, S. 2010. Analisis Kualitatif dan Kuantitatif Formaldhehid pada Ikan Asin di Madura. Jurnal Agrointek. 4(2):132-137

Khoirudin, A. 2017. Kajian Kandungan Formalin pada Produk Tahu dengan Metode Kualitatif dan Kuantitatif Di Kota Bandung. Program Studi Teknologi Pangan Fakultas Teknik Universitas Pasundan Bandung. Bandung

Mahmudatussa'adah, Ai. 2014. Karakteristik Warna dan Aktivitas Antioksidan Antosianin Ubi Jalar Ungu. Fakultas Teknologi Pertanian Institut Pertanian Bogor, Bogor.

Nuhman dan Wilujeng, A. 2017. Pemanfaatan Ekstrak Antosianin Dari Bahan Alam Untuk Identifikasi Formalin Pada Tahu Putih. Universitas Hang Tuah, Surabaya.

PECSOK, R.L., L.D. SHILEDS, T. CAIRNS, and I.G. MCWILLIAM. 1976. Modern Methods of Chemical Analysis. 2nd ed. John Wiley \& Sons, Inc. New York.

Seidel, V. 2006. Initial and Bulk Extraction, In: Sarker, S. D., Latif, Z., \& Gray, A. I., (eds) Natural Product Isolation, 27- 46, Humana Pers, New Jersey.

SKOOG, D.A. and D.M. WEST. 1971. Principles of Instrumental Analysis. Holt, Rinehart and Winston, Inc., New York.

Yuliarti, N. 2007. Awas! Bahaya di Balik Lezatnya Makanan. Yogyakarta. Andi 